\title{
Degradation of Atrazine by Soil Bacteria in the Stationary Phase
}

\author{
Roongnapa Korpraditskul, * Arata Katayama** and Shozo Kuwatsuka \\ Laboratory of Soil Science, Faculty of Agriculture, Nagoya University, \\ Chikusa-ku, Nagoya 464-01, Japan
}

(Received January 25, 1993; Accepted July 19, 1993)

\begin{abstract}
Two atrazine-degrading bacteria, RK014 from Anjo (Japanese) soil and RK016 from Pak Chong (Thai) soil, were isolated. The isolate RK014 was an unidentified, Gram negative and non spore-forming rod, while RK016 was classified into Bacillus sp. The study on the degradation of atrazine in tenfold diluted nutrient broth containing $10 \mathrm{mg} / l$ of atrazine revealed that atrazine was degraded mainly at stationary phase in both bacterial cultures. Higher than $10^{8}-10^{9} \mathrm{cfu} / \mathrm{ml}$ of initial cell density was required for rapid degradation. The degradation rate of atrazine was higher at $\mathrm{pH} 8$ than $\mathrm{pH} 5$ in both cultures with the high density of inoculum. Deethylatrazine was a major metabolite by both isolates in the cultures. It is suggested that these characteristics of atrazine-degrading bacteria caused the slow microbial degradation of atrazine in soils in spite of ubiquitous presence of degrading microorganisms at $10^{5} \mathrm{MPN} / \mathrm{g}$-soil.
\end{abstract}

\section{INTRODUCTION}

The ubiquity of degraders among Thai and Japanese soils was suggested by the findings of Korpraditskul et al. ${ }^{1)}$ that the population of atrazine-degrading microorganisms was higher than $10^{5} \mathrm{MPN} / \mathrm{g}$-soil in the two soils examined. The microbial degradation in the soils appeared to take a distinctive role in atrazine degradation after 20 days of incubation, though in a minor contribution. The low and slow appearance of activity in the microbial degradation of atrazine in the soils was discordant to the relatively high population of atrazine degraders. It was reported that atrazine was rapidly degraded by some soil fungi and that $73 \%$ of atrazine was deethylated within 32 days. $^{2)}$ There was also the evidence that soil microorganisms could degrade $s$-triazine herbicides in the pure cul-

* Present address: Environmental Science Laboratory, Central Laboratory and Greenhouse Complex, Kasetsart University, Kamphaensaen, Nakhon, Pathom, 73140 Thailand.

** To whom all correspondence should be addressed. tures. $^{3-6)}$

In order to elucidate this contradictory phenomenon, the atrazine-degrading bacteria were isolated from the soils and the characteristics in atrazine degradation was examined in this study.

\section{MATERIALS AND METHODS}

\section{Standard Chemicals}

Reference standards used were atrazine (2chloro-4-ethylamino-6-isopropylamino-1,3,5triazine, $99.3 \%$ of purity), deethylatrazine (DEA, 4-amino-2-chloro-6-isopropylamino1,3,5-triazine, $98.2 \%$ of purity) and deisopropylatrazine (DIA, 6-amino-2-chloro-4ethylamino-1,3,5-triazine, $98.0 \%$ of purity). DEA was contained in standard atrazine at $0.013 \%$ and DIA was less than $0.001 \%$. All reference standards were gifted from CibaGeigy (Japan) Limited.

\section{Soil}

Anjo (Japanese) and Pak Chong (Thai) soils were used to isolate atrazine-degrading microorganisms. Soil preparations and properties 
were reported previously. ${ }^{1,7)}$

\section{Isolation of Atrazine-Degrading Micro- organisms}

Atrazine-degrading microorganisms were isolated from the cultures in dilution series with a Most Probable Number method reported by Korpraditskul et al. ${ }^{1}$ The highestdiluted cultures that showed the decrease of atrazine or those which exhibited peaks of metabolites on the gas chromatograms were used for the isolation by a spread-plate method. The agar medium was made by tenfold diluted nutrient broth (Eiken, Tokyo, Japan) and $1.5 \%$ agar (Nakarai Chemical, Tokyo, Japan). Colonies formed were further transferred repeatedly on the medium until each pure culture was obtained. The dominant microbes were judged based on the morphology of colonies after the observation by a microscopy with a low-power magnification. Each purified colony was cultured in tenfold diluted nutrient broth $(1 / 10 \mathrm{NB})$ for $24 \mathrm{hr}(\mathrm{pH} 6.8$, $\left.30^{\circ} \mathrm{C}\right)$. Cells were centrifuged at $10,000 \times g$ for $10 \mathrm{~min}$ and washed with a physiological saline. The washed cell suspension was inoculated to give higher than $10^{8} \mathrm{cfu} / \mathrm{ml}$ of density for Gram-positive bacteria and higher than $10^{9} \mathrm{cfu} / \mathrm{ml}$ of density for Gram-negative ones into $10 \mathrm{ml}$ of fresh $1 / 10 \mathrm{NB}$ containing $10 \mathrm{mg} / \mathrm{l}$ of atrazine. The control without inoculation was prepared in parallel. Atrazine was added as $100 \mu \mathrm{l}$ of acetone solution after sterilization passing through a membrane filter with $0.2 \mu \mathrm{m}$ of pore size. After appropriate intervals of incubation, the amount of atrazine remaining in the culture was determined as described below. The degradation of atrazine was evaluated by the percentage decrease based on the amount of atrazine remaining in control.

\section{Taxonomic Characterization of Isolates}

Some taxonomic characteristics of isolates were tested for identification. Catalase production was determined with $3 \% \quad \mathrm{H}_{2} \mathrm{O}_{2}{ }^{8}{ }^{8}$ Oxidase test was with a tetramethyl-paraphenylene-diamine dihydrochloride test paper (oxidase test paper, ${ }^{\circledR}$ Eiken, Tokyo, Japan) ${ }^{8}{ }^{8}$ OF-test was carried out using a commercial OF test media by supplier's protocol (Nissui,
Tokyo, Japan).

\section{Growth Stage and Atrazine Degradation}

The $1 / 10 \mathrm{NB}$ containing $10 \mathrm{mg} / \mathrm{l}$ of atrazine ( $\mathrm{pH}$ 6.8) was inoculated with one loopful of the $24 \mathrm{hr}$-old culture of the isolate RK014 or RK016, which gave $10^{3}$ to $10^{4} \mathrm{cfu} / \mathrm{ml}$ of density. Under shaking condition at $30^{\circ} \mathrm{C}$, the growth was monitored by means of $\mathrm{OD}_{660}$ and the concentration of atrazine remaining in the medium was measured by gas chromatography. The control without inoculation was also prepared in parallel. The degradation was evaluated by the comparison of remaining atrazine.

\section{Effect of $p H$ on Atrazine Degradation}

The isolate RK016 was cultured in $1 / 10 \mathrm{NB}$. At an early stationary phase of growth, the cells were collected, washed with sterile water and inoculated into $10 \mathrm{ml}$ of a basal salt medium, which consisted of $1.6 \mathrm{~g}$ of $\mathrm{K}_{2} \mathrm{HPO}_{4}$, $0.4 \mathrm{~g}$ of $\mathrm{KH}_{2} \mathrm{PO}_{4}, 0.3 \mathrm{~g}$ of $\mathrm{NH}_{4} \mathrm{NO}_{3}, 0.2 \mathrm{~g}$ of $\mathrm{MgSO}_{4} \cdot 7 \mathrm{H}_{2} \mathrm{O}, 0.1 \mathrm{~g}$ of $\mathrm{NaCl}$ and $0.02 \mathrm{~g}$ of $\mathrm{CaCl}_{2}$ in $1 l$ of distilled water. The initial cell density was $10^{8} \mathrm{cfu} / \mathrm{ml}$ in the medium. Before the inoculation, $\mathrm{pH}$ of the medium was adjusted to 4 and 5 with $100 \mathrm{~mm}$ citrate-200 mM phosphate buffer, and at $\mathrm{pH} 6,7$ and 8 with $100 \mathrm{~mm}$ phosphate buffer. Atrazine was added to the culture as described above. The initial concentration of atrazine was $10 \mathrm{mg} / l$. The control was prepared in the same manner after killing cells by autoclaving. After 30 days of incubation, the remaining amount of atrazine was determined as described below and the degradation percentage was calculated by the remaining amount in the control culture. The viable cells after 30 days of incubation were enumerated using an agar medium that consisted of the same basal salts as above and $0.1 \mathrm{~g} / \mathrm{l}$ of glucose instead of atrazine as carbon source.

\section{Atrazine and N-Dealkylated Metabolites Determination}

After incubation, to determine the concentration of atrazine and its $N$-dealkylated metabolites in the culture, $2 \mathrm{ml}$ of the culture suspension was transferred to a screw-capped tube, mixed with $1 \mathrm{ml}$ of acetone and $2 \mathrm{ml}$ of 
$10 \% \mathrm{NaCl}$, and then extracted with $3 \mathrm{ml}$ of diethyl ether by shaking mechanically for 30 min. The extract was directly analyzed by gas chromatography since there was no interfering peak. The operating conditions were described in the previous report. ${ }^{1)}$ The recoveries of atrazine, deethylatrazine and deisopropylatrazine were $93 \pm 8 \%, 86 \pm 9 \%$ and $78 \pm 8 \%$, respectively.

\section{RESULTS AND DISCUSSION}

\section{Isolation of Atrazine Degraders}

In the previous paper, ${ }^{1)}$ atrazine-degrading microorganisms were enumerated by a Most Probable Number method. From the positive cultures in the experiment, which showed the decrease in atrazine amount, microorganisms were isolated by a dilution plate technique. The dominant bacteria judged by morphology of colonies, 5 isolates from Pak Chong soil and 8 isolates from Anjo soil, were obtained. Atrazine-degrading ability was examined for each isolate using a large inoculum size giving higher than $10^{8}$ to $10^{9} \mathrm{cfu} / \mathrm{ml}$ of density. The isolate RK014 from Anjo soil degraded $25.5 \%$ of atrazine after 9 days of incubation and the isolate RK016 from Pak Chong soil degraded $35.2 \%$ of atrazine.

To isolate atrazine-catabolizing bacteria, some kinds of mineral media containing atrazine as the sole carbon and/or nitrogen source were also used. However, no degrader was obtained. This suggests that dominant soil microorganisms do not degrade atrazine catabolically but incidentally.

Figure 1 shows that both isolates were rod-
Table 1 Taxonomic claracteristics of the atrazine-degrading bacteria isolated.

\begin{tabular}{lcc} 
& \multicolumn{2}{c}{ Isolates } \\
\cline { 2 - 3 } & RK014 & RK016 \\
\hline Gram reaction & - & + \\
Shape & Rod & Rod \\
Spore & - & Endospore \\
Mobility & + & + \\
Catalase & + & + \\
Oxidase & + & + \\
OF-test & - & Oxidative
\end{tabular}

shaped bacteria. Some taxonomic characteristics of the two isolates are shown in Table 1. Isolate RK014 was an unidentified, non sporeforming, Gram-negative bacterium. The isolate RK016 carrying endospore was identified as Bacillus sp. ${ }^{8)}$ Bacteria classified into the genus Bacillus sp. have been reported as the major bacteria in Pak Chong soil. ${ }^{\text {) }}$

\section{Growth Stage and Atrazine Degradation}

Figure 2 shows that atrazine was degraded by both bacteria RK014 and RK016 in the stationary phase. Cell proliferation monitored by $\mathrm{OD}_{660}$ showed that the growth of RK016 was slightly faster than RK014. Isolates RK014 and RK016 started the exponential growth after 14 and $10 \mathrm{hr}$ of lag periods, respectively. After one day of incubation, the $\mathrm{OD}_{660}$ values became the highest that corresponded to $1.8 \times 10^{8} \mathrm{cfu} / \mathrm{ml}$ for RK014 and $2.4 \times 10^{7} \mathrm{cfu} / \mathrm{ml}$ for RK016. Then, the $\mathrm{OD}_{660}$ values decreased sharply and remained con-

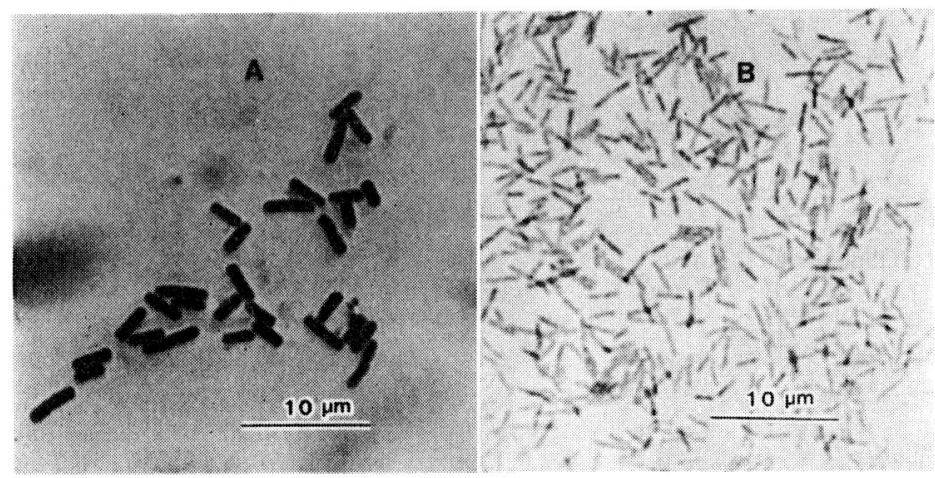

Fig. 1 Morphological shape of the isolates RK016 (A) and RK014 (B) after 24 hr of incubation in tenfold diluted nutrient broth. 
stant for a long time. In this stationary phase, both bacteria kept $10^{6} \mathrm{cfu} / \mathrm{ml}$ of population. The degradation of atrazine occurred after 8 days of incubation in the culture of RK014 and after 10 days in the culture of RK016. The change of $\mathrm{pH}$ mainly occurred during the exponential growth phase and the $\mathrm{pH}$ value became constant at 8 in the stationary phase. Chemical degradation of atrazine does not occur at $\mathrm{pH} 8$, which was shown by less than 3\% decrease in atrazine concentration after 30 days in phosphate buffer at $\mathrm{pH} 8$. Thus, atrazine was degraded through biological activity. This is the first evidence that atrazine is degraded by microorganisms at stationary phase.

In the past, many microorganisms capable
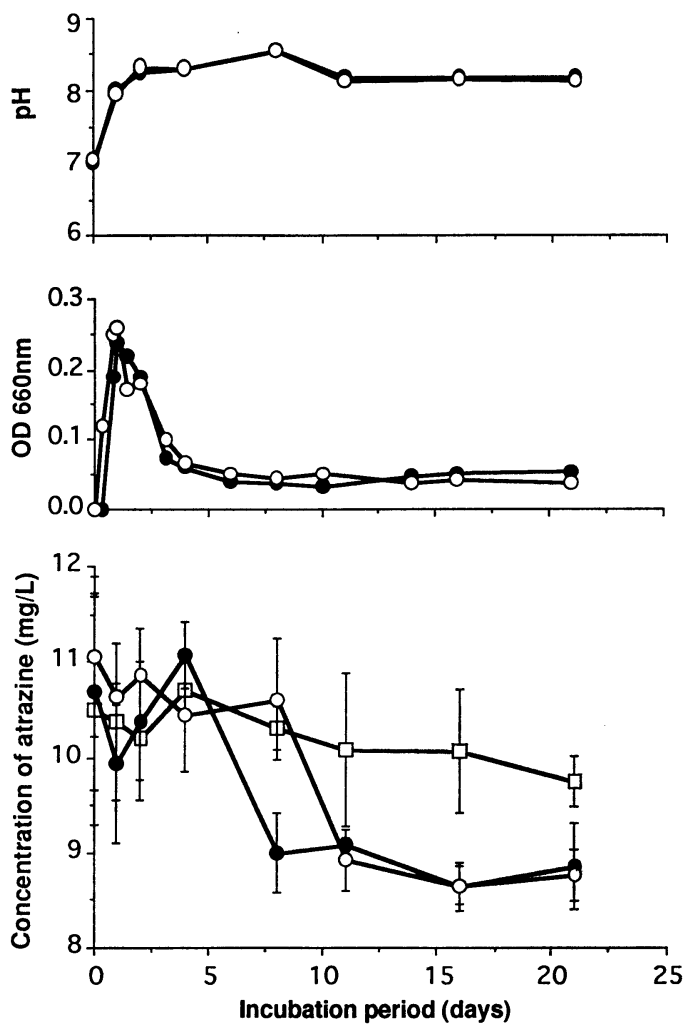

Fig. 2 Changes of $\mathrm{pH}$, optical density at $660 \mathrm{~nm}$ and the atrazine concentration in the cultures of atrazine-degrading bacteria RK014 (•) and RK016 (O).

Atrazine concentration in control culture is represented by $\square$. Bars represent the standard deviation of triplicated experiment. of degrading $s$-triazine herbicides including atrazine have been isolated..$^{2-6,10,11)}$ A slow and continuous rate of degradation has often been observed. ${ }^{10)}$ An incidental or nonpreferential involvement of $s$-triazine herbicides in microbial metabolism has been suggested as a degrading mechanism. ${ }^{10)}$ However, there has been no report on relation between the degradation and the physiology of microorganisms, i.e. the growth stage.

\section{Effect of $p H$ on Atrazine Degradation}

The washed cells of RK016 were inoculated into basal salt medium and incubated for 30 days. The results shown in Fig. 3 revealed the highest rate of degradation occurred at $\mathrm{pH}$ 8. The same tendency was observed in the case of RK014 as shown in Table 2. The higher degradation rate at higher $\mathrm{pH}$ is consistent with the previous findings ${ }^{1)}$ that the contribution of microbial degradation to total atrazine degradation was higher in soils at $\mathrm{pH}$ 7 and 8 than at $\mathrm{pH} \mathrm{4,5}$ and 6 .

The initial cell density of RK016 inoculated was $10^{8} \mathrm{cfu} / \mathrm{ml}$. Viable population decreased to about $10^{6} \mathrm{cfu} / \mathrm{ml}$ during incubation irrespective of $\mathrm{pH}$ values. This agreed with the

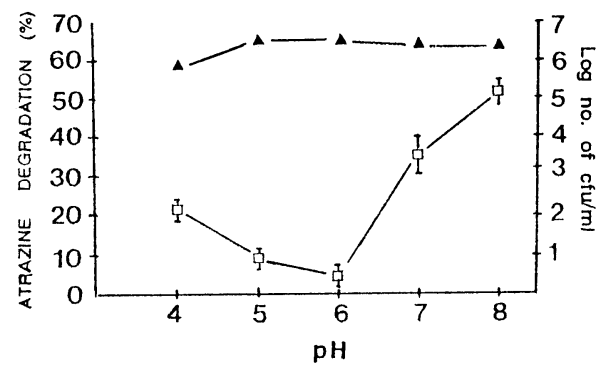

Fig. 3 Degradation of atrazine by isolate RK016 in basal salts medium after 30 days of incubation.

Adjustment of $\mathrm{pH}$ was carried out using citratephosphate buffer for $\mathrm{pH} \mathrm{4,5}$ and 6 and phosphate buffer for $\mathrm{pH} 7$ and 8 . The percentage of atrazine degradation ( $\square$ ) was calculated based on the remaining amount of atrazine in the control culture to cancel the effect of chemical degradation. The initial density of RK016 was $10^{8} \mathrm{cfu} /$ $\mathrm{ml}$. The number of viable cells $(\mathbf{\Lambda})$ was counted after the incubation in the same medium with glucose instead of atrazine. Bars represent the standard deviation of triplicated experiment. 
Table 2 The concentrations of atrazine and $N$-dealkylated metabolites detected in the cultures of RK014 and RK016 after 3 months of incubation. ${ }^{\text {a) }}$

\begin{tabular}{|c|c|c|c|c|c|c|}
\hline & \multicolumn{3}{|c|}{ pH 8} & \multicolumn{3}{|c|}{ pH 5} \\
\hline & $\begin{array}{c}\mathrm{ATZ} Z^{\mathrm{b})} \\
(\mathrm{mg} / l)\end{array}$ & $\begin{array}{c}\left.\mathrm{DEA}^{\mathrm{b}}\right) \\
(\mu \mathrm{g} / l)\end{array}$ & $\begin{array}{c}\mathrm{DIA}^{\mathrm{b})} \\
(\mu \mathrm{g} / l)\end{array}$ & $\begin{array}{c}\mathrm{ATZ} \\
(\mathrm{mg} / l)\end{array}$ & $\begin{array}{l}\text { DEA } \\
(\mu \mathrm{g} / l)\end{array}$ & $\begin{array}{c}\text { DIA } \\
(\mu \mathrm{g} / l)\end{array}$ \\
\hline Control & 11.1 & 115.2 & 9.1 & 7.1 & 50.0 & 12.0 \\
\hline RK014 & 9.9 & 658.7 & 76.9 & 7.9 & 320.0 & 23.0 \\
\hline RK016 & 3.2 & 202.9 & 14.8 & 5.9 & 999.0 & 86.5 \\
\hline
\end{tabular}

a) The medium was tenfold diluted nutrient broth containing about $11 \mathrm{mg} / \mathrm{l}$ of atrazine. Adjustment of $\mathrm{pH}$ was carried out using phosphate buffer for $\mathrm{pH} 8$ and citrate-phosphate buffer for $\mathrm{pH} 5$. The results were shown as the mean of duplicated experiment.

b) ATZ, atrazine; DEA, deethylatrazine; DIA, deisopropylatrazine.

atrazine degradation by the bacteria at stationary phase.

\section{Production of $N$-Dealkylated Metabolites from Atrazine}

The isolates RK016 and RK014 were cultured for 3 months in $1 / 10 \mathrm{NB}$ containing about $11 \mathrm{mg} / l$ of atrazine at $\mathrm{pH} 5$ and $\mathrm{pH} 8$. As shown in Table 2, deethylatrazine (DEA) and deisopropylatrazine (DIA) were detected. In the control cultures, DEA and DIA were detected at the same level of original amount. Significantly higher amounts of DEA and DIA in the cultures of RK014 and RK016 compared to the control cultures suggest that these metabolites were produced by the bacteria as metabolites. The amount of DEA was much higher than DIA. These results were supported by previous reports that the microbial degradation of atrazine started from the deethylation or the deisopropylation of the side chains. ${ }^{2-6,11)}$ Only DEA has been detected with atrazine in the environment. ${ }^{12-14)}$ It is possible that the isolates in this study play a major role in the microbial degradation of atrazine in soil.

At $\mathrm{pH} \mathrm{5,} \mathrm{the} \mathrm{decrease} \mathrm{of} \mathrm{atrazine} \mathrm{in} \mathrm{the}$ control culture indicated the chemical degradation under acidic conditions. Almost no accumulation of DEA and DIA was observed. This agreed with the findings that the chemical degradation of chloro-s-triazines under acidic conditions occurs through hydrolysis of chlorine. ${ }^{15)}$

At $\mathrm{pH} 8$, the decrease in mass balance in both bacterial cultures compared with that in control indicated the further degradation of atrazine metabolites by bacteria.

\section{Relation with Slow Microbial Degradation in Soil}

The degradation activity was highest at $\mathrm{pH}$ 8. The accumulation of DEA was observed in the bacterial degradation. These results suggested that the bacterial isolates were involved in the microbial degradation of atrazine in soil. It was found that atrazine was degraded by both bacteria RK014 and RK016 at stationary phase. This can be one of the reasons why microbial degradation of atrazine in soil was very slow in spite of the presence of degrading microorganisms. The insufficient cell density of the degrading microorganisms in soil also can be one of the reasons for the slow microbial degradation in soil. The cell density higher than $10^{8}$ or $10^{9} \mathrm{cfu} / \mathrm{ml}$, which resulted in the high rate of atrazine degradation in the cultures, has not been observed in soil, where the population density of degraders was $10^{5}$ to $10^{6} \mathrm{MPN} / \mathrm{g}$-soil. ${ }^{1)}$ It is still unknown what mechanisms are involved in this atrazine transformation by these bacteria at the stationary phase. Further experiment on atrazinedegrading enzymes involved and their function at low and high $\mathrm{pH}$ should be conducted.

\section{ACKNOWLEDGMENTS}

Gratitude is extended to Professor Makoto Kimura in our laboratory for his invaluable suggestions and constructive comments during the study.

\section{REFERENCES}

1) R. Korpraditskul, A. Katayama \& S. Kuwa- 
tsuka: J. Pesticide Sci. 18, 77 (1993)

2) D. D. Kaufman \& J. Blake: Soil Biol. Biochem. 2, $73(1970)$

3) M. C. Giardina, M. T. Giardi \& J. Filacchioni: Agric. Biol. Chem. 44, 2067 (1980)

4) M. C. Giardina, M. T. Giardi \& J. Filacchioni: Agric. Biol. Chem. 46, 1439 (1982)

5) A. M. Cook \& R. J. Hutter: J. Agric. Food Chem. 29, 1135 (1981)

6) A. M. Cook \& R. J. Hutter: J. Agric. Food Chem. 32, 581 (1984)

7) R. Korpraditskul, V. Korpraditskul \& S. Kuwatsuka: J. Pesticide Sci. 17, 287 (1992)

8) N. R. Krieg (ed.) \& J. G. Holt (Editor in chief): "Bergey's Manual of Systematic Bacteriology," Vol. 1, Williams \& Wilkins, Baltimore/London, p. 964,1984

9) N. Thaveechai: Personal communication, Dept. Plant Pathology, Kasetsart University, Thailand

10) D. D. Kaufman \& P. C. Kearney: Residue Rev. 32, 235 (1970)

11) R. M. Behki \& S. U. Khan: J. Agric. Food Chem. 34, 746 (1986)

12) D. A. Belluck, S. L. Benjamin \& T. Dawson: "Pesticide Transformation Products," ed. by L. Somasundaram \& J. R. Coats, ACS Symposium Series 459, American Chemical Society, Washington, D. C., pp. 254-273, 1991

13) S. U. Khan \& P. B. Marriage: J. Agric. Food Chem. 25, 1408 (1977)

14) D. C. Muir \& B. E. Baker: J. Agric. Food Chem.
24, 122 (1976)

15) D. E. Armstrong \& J. G. Konrad: "Pesticides in Soil and Water," ed. by W. D. Guenzi, J. L. Ahlrichs, G. Chesters, M. E. Bloodworth, R. G. Nash, R. C. Dinauer, M. E. Davis \& L. Eisele, Soil Science Society of America, Inc., Madison, Wisconsin, pp. 123-132, 1974

\section{要 約}

\section{定常期にある土壇細菌によるアトラジンの分解} Roongnapa KoRPRADITSKUL, 片山新太

鎯塚昭三

アトラジン分解細菌 RK014 株と RK016 株がそれ ぞれ安城土钲 (日本) および Pak Chong 土壌 (タイ) か ら単離された。 RK014 株はグラム陰性の胞子を形成し ない非発酵性かん菌であった。 RK016 株は Bacillus 属細菌と同定された. 10 分の 1 希釈の普通ブイヨン培 地中で，定常期にある細菌によりアトラジンは分解され た.急速な分解には， $10^{8} \sim 10^{9} \mathrm{cfu} / \mathrm{ml}$ 以上の高い初期 菌密度が必要であった. $\mathrm{pH}$ 条件が 5 よりも 8 のほうが 分解速度が高かった. Deethylatrazine が両菌株の主 要代謝産物であった．このようなアトラジン分解細菌の 性質が，広く土壃中に $10^{5} \mathrm{MPN} / \mathrm{g}$ 土裹で分解菌が存在 するにもかかわらず，土堙中でのアトラジンの微生物分 解が非常に遅い原因となっていることが示唆された。 